\title{
Study of Electrolyte Changes in Tuberculosis And Human Immune Deficiency Virus (HIV) Co-Infected with Tuberculosis Patients : A Hospital Based Study
}

\author{
Dr S.N.Bhagyamma ${ }^{1}$, Dr.U.Sreeenivasulu ${ }^{2}$, Dr R.Anuradha ${ }^{3}$ \\ ${ }^{I}$ (Assistant Professor, Department Of Biochemistry, Govt. Medical College, Anantapuramu, Andhra Pradesh, \\ India) \\ ${ }_{2}^{2}$ (Assistant Professor, Department Of Biochemistry, Govt. Medical College, Anantapuramu, Andhra Pradesh, \\ India) \\ ${ }_{3}^{3}$ (Associate Professor, Department Of Biochemistry, Govt. Medical College, Anantapuramu, Andhra Pradesh, \\ India)
}

\begin{abstract}
Tuberculosis is the commonest infection among HIV (Human Immunodeficiency Virus) patients. This co-infection constitutes a major death threat in the world. Electrolyte disturbances have been reported in both Tuberculosis (TB) infection lone and TB-HIV co-infected patients. The main objectives of the study is to evaluate electrolyte imbalance among Tuberculosis (TB) patients alone and HIV co-infected with Tuberculosis (TB) patients. A total of 120 subjects participated in this study. They were divided in to 3 groups as follows. Group 1 contains 40 normal healthy controls without TB or HIV infection, group 2 contains 40 new positive cases of HIV co-infected with Tuberculosis (TB). All subjects were screened for the presence and absence of TB, $H I V$ and the levels of electrolytes in plasma (sodium, potassium, and chloride) were estimated by electrolyte kit method by using semi-auto Analyzer. Level of plasma sodium in TB patients were significantly higher when compare with $T B / H I V(141.1 \pm 1.21$ vs $137.4 \pm 2.81 \mathrm{~m}$ eqll) and healthy controls $(135.9 \pm 1.37$ meq/l). Plasma Potassium level significantly higher in TB/HIV patients when compared with Tuberculosis $(4.10 \pm 0.49 \mathrm{VS}$ $3.39 \pm 0.20$ meq/l) and healthy controls $(3.79 \pm 0.27$ meq/l). Plasma chloride level was significantly higher in

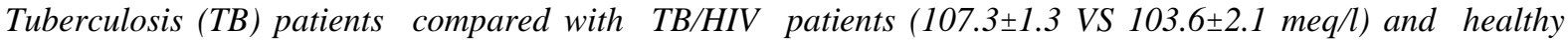
controls $(101.4 \pm 2.89 m e q /)$. Hyperkalemia and hyponatremia and hypochloremia are commonly encountered electrolyte disturbances in TB/HIV infection. Hypernatremia and hypokalemia and hyperchloremia are the electrolyte disturbances in Tuberculosis (TB) patients. We concluded that Electrolyte balance monitoring in patients with Tuberculosis is recommended once treatment is recommended. Because of high incidence of the electrolyte disturbances with HIV infected patients, close monitoring and aggressive management are mandatory.
\end{abstract}

Keywords: Tuberculosis, Human Immunodeficiency Virus, Electrolyte imbalance

\section{Introduction}

By the advent of 21st century, medical science could control many of the previously incurable diseases. A notable exception is AIDS, which continuous to challenge mankind. There are millions of seropositive cases to be found across the globe. Every minute around 12 people become newly infected with HIV. India has the second largest number of HIV-infected people (the estimate is about 8 million persons) [1].

AIDS is retroviral disease caused by human immunodeficiency virus (HIV) . Transmission of AIDS essentially requires the exchange of body fluids (semen, vaginal secretions, blood, milk) containing the virus or virus-infected cells. There are three major routes of HIV transmission-sexual contact, parenteral inoculation and from infected mothers to the newborns[2].

Tuberculosis (TB) also occurs earlier in the course of HIV infection than many other opportunistic infections. The risk of death in co-infected individuals is also twice that of HIV infected individuals without TB ,even when cd4 cell count and anti retroviral therapy are taken into account [3]Tuberculosis is a major cause of morbidity and death .It accounts for 2-3 million deaths per annum, globally [4].

Factors contributing to the resurgence of tuberculosis in developing countries include co-infected with HIV, emergence of multiple resistant Tuberculosis inadequate treatment, poverty, malnutrition, increased number of displaced persons. Diarrhoea, vomiting and excessive sweating are common features of HIV [5].

Sodium is the chief cation of the extracellular fluid .In association with chloride and bicarbonate ,sodium regulates the body acid-base balance. Sodium also required for the maintenance of osmotic pressure and fluid balance. Potassium is the principle intracellular cation and is required for the regulation of acid-base balance and water balance in the cells. Chloride is a constituent of sodium chloride hence the metabolism of chlorine and sodium are intimately related and is involved in the regulation of acid-base equilibrium, fluid 
balance and osmotic pressure. These functions are carried out by the interaction of chloride with $\mathrm{Na}+$ and $\mathrm{K}+[6]$.

Fluid electrolyte and acid-base derangements frequently encounter in AIDS and TB have been found to be major factors for the development of acute renal failure[7]. Hyponatremia is a frequent finding among HIV-infected persons, with a reported prevalence of 30-60\% in hospitalized patients [8] and It is a marker of severe illness that is associated with increased mortality in HIV-infected patients [9] . Hyperkalemia has been described in up to 15 to $20 \%$ of hospitalized patients with HIV[10].

The aim of the present study is to know the Serum electrolyte changes including sodium, potassium, chloride among HIV-TB coinfected patients

\section{Material and methods}

A total of 120 subjects were taken for this study. They were divided in to 3 groups as follows. Group 1 contains 40 subjects who were apparently healthy were used as controls, group 2 contains 40 subjects were new positive cases of Tuberculosis (TB) who are not on drugs, group 3 contains 40 new positive cases of Tuberculosis co-infected with HIV infection who are not on drugs. In all the subjects electrolyte levels (sodium, potassium and chloride) in plasma were determined using standard methods by using Semi- Auto analyzer (ROBONIC).

\subsection{Sample Collection:}

$5 \mathrm{ml}$ of venous blood was obtained from the cubital vein of each patient using a syringe into a lithium heparin bottle. The plasma was extracted by centrifugation for $10 \mathrm{~min}$ at $4000 \mathrm{rpm}$ into a plain tube and used for analysis of electrolytes. Plasma sodium, potassium and chloride were estimate by electrolyte kit method [11] By using semi-autoanalyzer (Robonic company).

\subsection{Exclusion Criteria:}

Patients with symptoms of malaria fever, Diabetes Mellitus, patients with intestinal infection which could lead to dysentery, pregnant women, women using contraceptives, patients on corticosteroid therapy, severe malnutrition and patients with symptoms of jaundice were excluded from the study.

\subsection{Statistical Analysis:}

Data were analyzed by using Graph pad software. All the data were expressed in mean and standard deviation. Test of probability less than $0.05(\mathrm{P}<0.05)$ was regarded as significant.

\section{Results}

The mean plasma sodium value was significantly lower in controls when compared with the new cases of Tuberculosis (TB) patients (Table 1) and Tuberculosis co-infection with HIV patients (Table 2). The mean plasma sodium was higher in new cases of TB when compared with Tuberculosis (TB) co-infected with HIV patients (Table 3).

The mean plasma potassium value was significantly higher in controls when compared with Tuberculosis (TB) patients (Table 1) and the mean plasma potassium value in Tuberculosis(TB) co-infected with HIV patients was higher when compared with controls (Table 2). The mean plasma potassium value was significantly higher in Tuberculosis (TB) co-infected with HIV patients when compared with new cases of Tuberculosis (TB) patients (Table 3).

The mean plasma chloride value was significantly higher in new cases of Tuberculosis (TB) when compared with controls (Table 1) and the mean potassium value was significantly lower in controls when compared with Tuberculosis (TB) co-infected with HIV patients (Table 2). The mean chloride value was significantly higher in new cases of Tuberculosis (TB) when compared with Tuberculosis (TB) co-infected with HIV patients (Table-3).

Table 1:Revealed the Mean \pm SD of plasma electrolytes $(\mathrm{Na}+, \mathrm{K}+, \mathrm{Cl}-)$ in Tuberculosis patients and healthy controls.

\begin{tabular}{|c|c|c|c|c|}
\hline Parameters & $\begin{array}{c}\text { Tuberculosis } \\
\text { patients }\end{array}$ & Healthy controls & t-value & p-value \\
\hline $\mathrm{Na}+(\mathrm{meq} / \mathrm{l})$ & $\mathbf{1 4 1 . 1} \pm \mathbf{1 . 2 1}$ & $\mathbf{1 3 5 . 9} \pm \mathbf{1 . 3 7}$ & $\mathbf{1 7 . 9 9}$ & $<0.0001 \mathrm{ESS}$ \\
\hline $\mathrm{K}+(\mathrm{meq} / \mathrm{l})$ & $\mathbf{3 . 3 9} \pm \mathbf{0 . 2 0}$ & $\mathbf{3 . 7 9} \pm \mathbf{0 . 2 7}$ & $\mathbf{7 . 5 2 9}$ & $<0.0001 \mathrm{ESS}$ \\
\hline $\mathrm{Cl}-(\mathrm{meq} / \mathrm{l})$ & $\mathbf{1 0 7 . 3} \pm \mathbf{1 . 3 1}$ & $\mathbf{1 0 7 . 3 5} \pm \mathbf{1 . 3 1}$ & $\mathbf{1 2 . 0 8 7}$ & $<0.0001 \mathrm{ESS}$ \\
\hline
\end{tabular}

$\mathrm{Na}+$-Sodium, K+ - Potassium, Cl- - Chloride, ESS - Extremely statically significant

Table 2: Revealed the Mean \pm SD of plasma electrolytes(Na+, $\mathrm{K}+, \mathrm{Cl}-$ ) in HIV co-infected with TB patients and healthy controls. 
Study of Electrolyte Changes in Tuberculosis And Human Immune Deficiency...

\begin{tabular}{|c|c|c|c|c|}
\hline Parameter & $\begin{array}{c}\text { HIV co infected with TB } \\
\text { patients }\end{array}$ & Healthy controls & t-value & p-value \\
\hline $\mathrm{Na}+(\mathrm{meq} / \mathrm{l})$ & $137.4 \pm 2.81$ & $135.9 \pm 1.37$ & 3.043 & $\mathrm{P}=0.0032 \mathrm{SS}$ \\
\hline $\mathrm{K}+(\mathrm{meq} / \mathrm{l})$ & $4.10 \pm 0.49$ & $3.79 \pm 0.27$ & 5.656 & $<0.0001 \mathrm{ESS}$ \\
\hline $\mathrm{Cl}-(\mathrm{meq} / \mathrm{l})$ & $103.65 \pm 2.10$ & $101.42 \pm 2.89$ & 3.975 & $\mathrm{P}=0.0002 \mathrm{ESS}$ \\
\hline
\end{tabular}

Na+ -Sodium, K+ - Potassium, Cl- - Chloride, TB - Tuberculosis, HIV - Human immunodeficiency virus, ESS Extremely statistically significant, SS - Statistically significant

Table 3: Revealed the Mean $\pm \mathrm{SD}$ of plasma electrolytes $(\mathrm{Na}+\mathrm{K}+, \mathrm{Cl}-)$ in Tuberculosis patients and $\mathrm{HIV}$ coinfected with TB .

\begin{tabular}{|c|c|c|c|c|}
\hline Parameter & Tuberculosis patients & HIV co-infected with TB & t-value & p-value \\
\hline $\mathrm{Na}+(\mathrm{meq} / \mathrm{l})$ & $141.1 \pm 1.21$ & $137.4 \pm 2.81$ & 7.64 & $<0.0001 \mathrm{ESS}$ \\
\hline $\mathrm{K}+(\mathrm{meq} / \mathrm{l})$ & $3.39 \pm 0.20$ & $4.10 \pm 0.49$ & 10.04 & $<0.0001 \mathrm{ESS}$ \\
\hline $\mathrm{Cl}-(\mathrm{meq} / \mathrm{l})$ & $107.35 \pm 1.31$ & $103.65 \pm 2.10$ & 9.47 & $<0.0001 \mathrm{ESS}$ \\
\hline
\end{tabular}

Na+ - Sodium, K+ - Potassium, Cl- - Chloride, TB - Tuberculosis, HIV - Human immunodeficiency virus, ESS-Extremely statistically significant, SS-Statistically significant

\section{Discussion}

India has one of the world's highest burdens of both Tuberculosis (1.96 million cases annually) and HIV infection 2.31 million prevalent cases [11]. Tuberculosis occurs earlier in the course of HIV infection than many other opportunistic infections. The risk of death in co-infected individuals is also twice that of HIV infected individuals without Tuberculosis, even when CD4 cell count and anti retroviral therapy are taken into account [3].

In the present study, mean serum sodium in HIV co-infected with TB patients was significantly low compared with new cases of TB (137.4 $\pm 2.81 \mathrm{VS} 141.1 \pm 1.21 \mathrm{meq} / \mathrm{l})$. Olalekan AW et al 2015 [12] reported that the mean sodium level in HIV co-infected with TB was significantly low when compared with new cases of pulmonary Tuberculosis (140.55 \pm 8.07 Vs $142.10 \pm 6.68 \mathrm{meq} / \mathrm{l})$. A study by Folaranmi OM et al 2004 [13] shows that mean sodium level in Tuberculosis patients is significantly high compared with HIV patients $(147.0 \pm 6.8$ Vs $125.8 \pm 5.8 \mathrm{meq} / \mathrm{l})$.

Hyponatremia in most of the AIDS infected patients is due to loss of sodium through diarrhea.[14].Defective renal sodium conservation due to HIV infection of the kidney itself can cause hyponatremia [15].

In the present study mean potassium level significantly high in HIV co-infected with TB compared to new cases of TB patients $(4.10 \pm 0.49$ VS $3.39 \pm 0.20$ meq/l). The obtained result was consistent previous studies by Olalekan et al 2015[12] shows the mean value of potassium in HIV co-infected with TB and TB patients (3.66 $\pm 0.42 \mathrm{VS} 3.07 \pm 0.42 \mathrm{meq} / \mathrm{l})$, Folaranmi OM et al 2004 [13] shows the mean value of potassium in HIV co-infected with TB and new cases of TB patients ( $4.9 \pm 0.82 \mathrm{Vs} 2.53 \pm 0.52 \mathrm{meq} / \mathrm{l})$.

The above observation can be attributed to the facts that in HIV/AIDS infection, there is the killing of cells of by virus high grade pyrexia /fever(causing destruction of cells) and therefore leading to the influx of $\mathrm{K}+$ from the cells to the plasma [16]. Major causes for Increased potassium levels include adrenal insufficiency, hyporeninemic hypoaldosteronism [17], administration of trimethoprim or pentamidine [18].

A total of 120 subjects were taken for this study. They were divided in to 3 groups as follows. Group 1 contains 40 subjects who were apparently healthy were used as controls, group 2 contains 40 subjects were new positive cases of Tuberculosis (TB) who are not on drugs, group 3 contains 40 new positive cases of Tuberculosis coinfected with HIV infection who are not on drugs. In all the subjects electrolyte levels (sodium, potassium and chloride) in plasma were determined using standard methods by using Semi- Auto analyzer (ROBONIC).

\section{Conclusion}

Hyponatremia, hypokalemia, hyperkalemia are common electrolyte disturbances. Tuberculosis(TB) co-infected with HIV patients. Because of the high incidence of the electrolyte disturbances with HIV infected patients, close monitoring and aggressive management are mandatory.

\section{Acknowledgments}

We are thankful to Rntcp and Naco staff for helping us while doing this study.

\section{References}

[1]. M.D. Rafi MD, Text book of Biochemistry for medical students, chapter 41, Immunochemistry, $2^{\text {nd }}$ edition, 748-753

[2]. U.Satyanarayana, U.Chakrapani. Biochemistry, $4^{\text {th }}$ edition, chapter 38, Acquired immunodeficiency syndrome(AIDS), 695-700.

[3]. S. Suchindram, S. Emily, Brouwer et al, Is HIV infection a risk factor for multi-drug resistant Tuberculosis? A systemic review. Plosane, 4(5), May 2009, 5561

[4]. H. Tomioka, K. Namba, development of antituberculous drugs; Current status and future prospects, Kekkaku, 81(12), 2006. 
[5]. A.V. Onwuliri. Total bilirubin, albumin, electrolytes and anion gap in HIV positive patients in Nigeria, J Med sci 4(3), 2004, 214220 .

[6]. U.Satyanarayana, U.Chakrapani, Biochemistry, $4^{\text {th }}$ edition, chapter 18, Mineral metabolism, 403-424.

[7]. R. Berggrem, V. Batuman, HIV-associated renal disorders :recent insights in to pathogenesis and treatment, Curr HIV/AIDS rep, 2, $2005,109-115$.

[8]. R.J. Glassock, A.H. Cohen, G. Danovitch et al, Human immunodeficiency virus (HIV) infection and the kidney, Ann Intern Med, $112,1990,35-49$.

[9]. W.W. Tanq, E.M. Kaptein, E.I. Feinstein et al, Hyponatraemia in hospitalized patients with acquired immunodeficiency syndrome (AIDS) and theAIDS-related complex, Am J Med, 94, 1993,169-74.

[10]. M.F. Kalin, L. Poretsky, D.S. Seres et al, Hyporeninemic hypoaldosteronism associated with acquired immunodeficiency syndrome, Am J Med, 82, 1987,1035.

[11]. R.G. Schoenfeld et al, clin chem 10 (1964) 533.12.World health organization. Global Tuberculosis control:surveillance ,planning,financing who report 2008;393.Geneva Switzerland.

[12]. A.W. Olalekan, F.A. Oluwaseum, Akeem AD et al, Evaluation of electrolyte imbalance among Tuberculosis patients receiving treatments in south western Nigeria, Alexandria Journal of Medicine, 51, 2015, 255-260.

[13]. O.M. Folaranmi, A.A. Adesiyan, Comparative study of plasma electrolytes(Na,k,cl and Hco3-) and urea levels in HIV/AIDS and pulmonary Tuberculosis infected subjected, Biokemstri, 16(1), 2004 June, 29-36.

[14]. T. Kaile, I. Zulu, R. Lumayi et al, Inappropriately low aldosterone concentrations in adults with AIDS-related diarrhea in Zambia : a study of response to fluid challenge, BMC Res, 1, 2008, 1:10.

[15]. A.J Cusano, H.L. Thies, F.P. Siegal et al, Hyponatremia in patients with Acquired immune deficiency syndrome. Acquir immune defic syndr, 3(10), 1990, 949-53.

[16]. J. Macleod, Davidson`s principle and practice of Medicine, $13^{\text {th }}$ edition, ELBS and CHURCHILL living stone, $1981,307$.

[17]. M.F. Kalin, L. Poretsky, D.S. Seres et al, Hyporeninemic hypoaldosteronism associated with acquired immunodeficiency syndrome, Am J Med, 82, 1987,1035.

[18]. M.J. Choi, P.C. Fernandez, A. Patnaik, Brief report : Trimethoprim-induced hyperkalemia in a patient with AIDS, N Engl J Med, $328,1993,703$. 